\title{
'The nation rejoices or mourns': literary and cultural ambivalences in Wendy Cope's Making Cocoa for Kingsley Amis (1986)
}

\section{Rory Waterman}

\section{Abstract}

The poet Wendy Cope gained a huge reputation in the early 1980s mainly for a series of witty and incisive parodies, often under the name of her desperate fictional poète maudit Jake Strugnell, and these poems were collected, along with others, in her hugely successful and influential debut collection, Making Cocoa for Kingsley Amis, which appeared in 1986 . This book sold almost 200,000 copies, but has been the subject of a very small body of criticism. Many of her contemporary poet-critics were dismissive: in one contemporary review, Peter Riley epitomized a not uncommon reaction when he claimed that no 'poetic import can be claimed for the book', and railed against 'a new audience for poetry, one which must be presumed to have previously fought shy of it as too difficult or too deep'. Certainly, Making Cocoa for Kingsley Amis is not a work of avant garde complexity, but Cope's debut is not as cosily complacent as such critics indicate. It is in fact highly allusive and resistant to orthodoxies - and was a thorn in the side of the literary and cultural establishment into which she was instantly propelled. This essay assesses the ways in which Cope's debut collection takes an ambivalent, nuanced, and parodic response to British institutions, and to the orthodoxies of the male-dominated literary world she was entering.

\section{Article}

Wendy Cope gained a huge reputation in the early 1980s mainly for a series of witty and incisive parodies, often under the name of her desperate fictional poète mauditJake Strugnell: as Anthony Thwaite puts it, she found 'her own voice ... as a parodist'. ${ }^{1}$ This was part of her apprenticeship as a poet: 
as she has said herself, 'To write a good parody of somebody's work you really have to look at it very carefully, so you learn a lot'.2 Many of these parodies first appeared in major press outlets such as the Spectator and Observer, as well as on the BBC and in popular and decidedly non-literary magazines such as Vogue, and were eventually collected with many other poems, some of which were more ostensibly personal, in Making Cocoa for Kingsley Amis. When that book appeared in 1986, leading one contemporary reviewer to describe her as the 'most accomplished parodist since Beerbohm', it made bestseller lists, selling in quantities almost unheard of for a poetry collection, and certainly for a debut. ${ }^{4}$

Making Cocoa for Kingsley Amis also inspired vitriol, directed towards both her and her audience. Reviewing the book in PN Review, one of the most prestigious poetry magazines in Britain, Peter Riley epitomized a not uncommon reaction when he claimed that no 'poetic import can be claimed for the book', and railed against 'a new audience for poetry, one which must be presumed to have previously fought shy of it as too difficult or too deep'. ${ }^{5}$ Certainly, it is not a work of avant garde complexity; but, as this essay demonstrates, Cope's debut is not as cosily complacent as such critics indicate. It is in fact highly allusive and resistant to orthodoxies - and was a thorn in the side of the literary and cultural establishment into which she was instantly propelled.

What is often overlooked is that the book begins with poems lampooning British institutions and customs, and often with serious critical intentions, gently yet insidiously antagonizing the establishment as much from within as from without. This subversive tendency is signalled to some extent in the first poem, 'Engineers' Corner', which makes a satirical stand against the marginalization of poetry while simultaneously lambasting tweedy parochialism: 'the person who can write a sonnet / Has got it made', she writes, with an irony she could not then have known would grow double, as she went on to earn enough from her writing to give up her day job. ${ }^{6}{ }^{6}$ That's why this country's going down the drain', it ends, the speaker embracing a kind of parochially conservative Daily Mail rhetoric about falling standards. 
The book's second poem, 'All-Purpose Poem for State Occasions', broadens the assault by cheerily making a mockery of State-sanctioned boilerplate. Its speaker is the generic author of a British 'State' poem tapping into the fervour of an unquestioning public who behave as that State would want them to. The Poet Laureate, John Betjeman, had died in 1984, and the poem was a response to a subsequent BBC commission to write about the Laureateship. ${ }^{7}$ Twelve years later, when Betjeman's successor Ted Hughes died, Tony Harrison, a favourite to replace him, would publish the poem 'Laureate's Block', attacking the eventual successor Andrew Motion as 'Di-deifying Motion', and putting himself out of contention for a position he would 'never seek'. ${ }^{8}$ Cope's poem, constructed from three limericks, uses mild satire rather than direct personal polemic, to ridicule the prospect of such poetic commitments:

The nation rejoices or mourns

As this happy or sombre day dawns.

Our eyes will be wet

As we sit round the set,

Neglecting our flowerbeds and lawns.

(Cocoa, p. 4)

While some examples exist of poems comprising multiple limerick stanzas which do not ridicule, cajole or vanish into ridiculousness, this is not one of them. Indeed, not only does it point up the rote tediousness of such tamely expectation-satisfying verse, it also ridicules the kowtowing instincts of a large proportion of the British population, from 'Dundee and Penzance and Ealing' - Scottish, Cornish, English (and presumably Welsh) - keen to pretend they 'love every royal', and then to use such fervour as an excuse to 'drink till we're reeling'. The apparent incongruity of the poem's form, frequently used for silly and often offensive subject matter, is a tacit rebuke both to the sententiousness of poems commissioned to reinforce such institutions and behaviours, and (more gently), the blind fealty of much of the coach-class public who are 'British and loyal' but do not question why, or what might serve them best. It also implies something about the way such behaviour might more properly be treated. 
The next poem, 'A Policeman's Lot', is then prefaced with an epigraph by thenPoet Laureate Ted Hughes: 'The progress of any writer is marked by those moments when he manages to outwit his own inner police system' (Cocoa, p. $5)$. This is surely made more difficult for a Laureate, in the service of patrons, who has effectively precluded himself from criticizing those patrons or the system upholding them in his poetry. Certainly, also, the epigraph and the mock-boilerplate 'State' poem immediately preceding it have contradicting speakers, the latter being an ironic epitome either of self-policing or the complete absence of independent thought. Like the speaker of 'All-Purpose Poem for State Occasions', the speaker of 'A Policeman's Lot' is in the service of the Crown, not of the art of poetry:

Although it's disagreeable and stressful (bull and stressful) Attempting to avert poetic thought ('etic thought), I could boast of times when I have been successful (been successful) And conspiring compound epithets were caught ('thets were caught).

In a style lifted from 'The Sergeant's Song' from Gilbert and Sullivan's The Pirates of Penzance, her policeman speaker is Hughes's 'inner' policeman, 'Patrolling the unconscious' of the 'prolific blighter' responsible for such psychologically complex works as The Hawk in the Rain and Crow, and having a tough time. Richard Collins and James Purnell call this poem 'an irresistible guying of Hughes's sententiousness', but for all its jocularity there is no implication that Cope disagrees with the words of Hughes she uses as an epigraph. ${ }^{9}$ As in its song intertext, the ends of most lines are echoed back in parentheses; when we read that 'the imagination of a writer (of a writer) / Is not the sort of beat a chap would choose (chap would choose)', we can almost imagine the parenthetical echoes coming not from a pack of British bobbies, as they are in 'The Sergeant's Song', but gleefully from Cope, from Hughes, from writers.

There is, then, a subtle implication, by dint of the poem's placement after Cope's dig at State-sanctioned poetry, that Hughes's 'subconscious' has been rendered a particularly difficult 'beat' due to his willingness to accept the Queen's shilling. The critic Louise Tondeur suggests that the poem 'satirises 
the idea' expressed in Hughes's epigraph but, as much as that, in the context of its placing in Making Cocoa for Kingsley Amis, it satirizes what might have been Hughes's unconscious at that time - and, through its ridiculous speaker, the officious British bobby on the beat and the system he upholds. As Tondeur goes on to note, a writer 'works best when s/he is not being watched by the "police system" or when the sense of being watched is sufficiently diminished', and the poem gives that a specifically British context. ${ }^{10}$

After three poems, then, Making Cocoa for Kingsley Amis has made a satirical stand against British institutions, which it also suggests are implicitly male (in 'Engineers' Corner', it is 'small boys' who do or do not 'dream of writing couplets / And spurn the bike, the lorry and the train'; her representative of the police is a 'chap'). The fourth poem, 'Reading Scheme', wittily shines a torch on the underbelly of dissatisfied family life, as well as sending up the Ladybird reading scheme Cope would have been familiar with through her work as a primary school teacher, a job she held for eighteen years. ${ }^{11}$ This poem adopts the repetitive form of the villanelle (with some substitutions in the repetends), as if to imitate the word patterns of a children's instructional reader. The poem essentially functions as a dual narrative, offering different interpretations to innocence and experience, much like Sandro Del-Prete's optical illusion Message d'Amour des Dauphins. ${ }^{12}$ The narrator is unreliably faux-naïve, and we must use our adult perspective to work out what is going on, which admittedly isn't difficult. Peter's and Jane's 'Mummy', who has 'baked a bun' - with all the connotative metaphorical weight of that phrase has a visit from the milkman who 'likes mummy' - with all the connotative weight of that circumstance - and is interrupted by the return of 'Daddy in his car' (Cocoa, p. 7).

This villanelle constantly tempts us to see the speaker as an adult attempting child-speak: though monosyllabic, 'glum' (ascribed to the milkman after the car arrives) is too complex a synonym for 'sad' to fit the register, 'Has he a gun?' is an allusion beyond the remit of the educational reading scheme book (if not, for example, a cartoon), and the line 'Go Peter! Go Jane! Come, milkman, come!' is, for the initiated, a crude pun. The poem is a window on 
wholesale dissatisfaction in a world of kept-up appearances, and the two children whose experience it inhabits might be happy now, but they are only blissful because of losable innocence. We see the world to which they can look forward.

With their two tangoing repetends, villanelles are inherently suited to obsessional themes. 'Lonely Hearts' is another ostensibly jocular, breezy example of the form, which uses its repetitions to comment on the nature of a different sort of text: the newspaper lonely hearts column. The five three-line stanzas present five separate voices with needs at once bespoke and shared, in consecutive advertisements by people who inadvertently reveal wants beyond those which are romantic. These are: a male biker who 'seeks female for touring fun' and hence escapism; a gay vegetarian 'whose friends are few' (my emphasis); an exec who wants the liberating second youth provided by 'bisexual woman, arty, young'; a 'Jewish lady with a son', who might have various religious and practical reasons to want support; and a Libran - the star sign most associated with a need for relationships ${ }^{13}$ - who is 'blue' and, uniquely here, explicitly confesses his or her 'need' for companionship (Cocoa, p. 17).

The repetends of 'Lonely Hearts' make insistent their speakers' various calls for love, and provide, in the context only of the column where their isolated needs are thrown together, a co-authored screed of longing for individuals who use the same phrases as one another throughout. They are brought together in the final stanza, where all share one voice, as well as one proxy home: 'Please write (with photo) to Box 152. / Who knows where it may lead once we've begun'? Though not unsympathetic, 'Lonely Hearts' also contains a subtle dig at their - our - superficiality. We can assume none of the hopefuls provide photos: lonely hearts columns, now superseded by a plethora of internet dating sites filled with detailed profiles, did not tend to allow for this, and none of the speakers of the poem promise to reciprocate. They all want more than they are able (or willing) to give.

The literary world, too, is presented as one of unreciprocated needs and missed opportunities, its cast as ridiculous as it is unfortunate. 'Emily 
Dickinson', the sole poem in the collection to mention a female poet, also takes a troubled figure for protagonist, and also relies on a slightly modulated and difficult fixed form to stab home its sharp point. A few small metrical substitutions notwithstanding, the poem is a double dactyl: an inherently humorous eight-line poetic form, with two dactyls comprising each line, the first of which is a compound adjective (here 'higgledy-piggledy'), and the sixth a single word. After highlighting that Dickinson 'Liked to use dashes / Instead of full stops', Cope writes that 'Critics and editors' no longer tolerate such 'Idiosyncrasy' (Cocoa, p. 13).

This is evidently a swipe at the proclivities of literary tastemakers and gatekeepers in her own time, about whom Cope can be defensively offensive: in 'Manifesto' she takes aim at 'a bloodless literary fart' critic (Cocoa, p. 32). However, the 'Nowadays' in 'Emily Dickinson' is a misfire, because it ignores the fact that Dickinson's immense posthumous popularity was partly facilitated by the revolution of literary modernism, which has permitted such 'idiosyncracies' of style to flourish.

Of course, the poem isn't a parody, most of which are in the second section of the book, and we shall come to them shortly. But three poems in the first section directly parody or josh with the poems or styles of two canonical poets: William Wordsworth and T. S. Eliot. The poet-subjects of her parodies and lampoons, all of which are men, are without exception presented in pofaced fashion as comically pompous and sententious, and this is never more the case than in 'A Nursery Rhyme as it might have been written by William Wordsworth'. However, as Andrew Bennett notes, this poem 'explores the pretensions of a certain idea of Wordsworth', rather than a more accurate version of the poet: like 'Emily Dickinson', it is happy to rest on a not altogether true (or fair) stereotype about its poet-subject, in this case humourless wonder..$^{14}$ It also formally echoes his predilection for rhymed pentameters. In the poem, the misty-eyed, fell-wandering speaker remembers a chance encounter with a talking sheep, who 'broke the moorland peace / With his sad cry, a creature who did seem / The blackest thing that ever wore a fleece' (Cocoa, p. 8). Walking 'towards him on the stony track', the speaker 
'asked him, "Have you wool upon your back?" / Thus he bespake: "Enough to fill three bags"'.

'Bespake' is cod-Wordsworthian, a comedic, decorous over-egging that does not appear in any of his poems. So is the conversation with the sheep, and the poem's self-absorbed valedictory couplet: 'And oft, now years have passed and I am old, / I recollect with joy that inky pelt'. And yet this line does have a near-parallel in one of Wordsworth's less celebrated poems, "The Oak and the Broom', in which a talking broom (gorse) bush is quoted thus:

Beneath my shade the mother-ewe Lies with her infant lamb; I see

The love, they to each other make, And the sweet joy, which they partake, It is a joy to me..$^{15}$

'Make love' has undergone a semantic shift since Wordsworth's day, to something explicitly sexual; but even when we take that into account, the anthropomorphized bucolic whimsy is at odds with modern sensibilities. Cope's poem also has a less obvious parallel text in William Kerr's artlessly grand and sentimental 'Counting Sheep':

I lingered at a gate and talked

A little with a lonely lamb.

He told me of the great still night ...

Of how, when sheep grew old,

As their faith told,

They went without a pang

To far green fields. ${ }^{16}$

So, Cope's and Kerr's poems are both ostensibly wistful (though sheep seem less sentimental than poets), and both have a solitary, presumably male, rural wanderer poet and a chatty sheep who passes on knowledge - though Kerr's is of the more familiar 'snow-white' variety. Kerr was one of the 'Georgian Poets', the anthologies of whose poetry sold in the tens of thousands from 1912 to 1922. He and most other Georgians have since fallen from view and acclaim, but he once took his place among the majority of that exclusively 
male, almost exclusively sub-Wordsworthian coterie who received rather more respect than they deserved, and who were not all above earnestly writing poems not incomparable to Cope's. Would the poem look out of place in one of the Georgian Poetry anthologies? Only just.

Facing this parody in a double page spread, to make an unlikely pair, is 'A Nursery Rhyme as it might have been written by T. S. Eliot'. (The nursery rhyme is 'Hickory Dickory Dock'.) This poem begins with a simple backhanded pastiche of 'Burnt Norton', the first of Eliot's Four Quartets. Cope writes: 'Because time will not run backwards / Because time / Because time will not run' (Cocoa, p. 9). While the previous parody evokes other poems and poets besides its main target, this one is as directly and intricately intertextual with its main target as it is ludicrously dismissive; the rest of the poem brings in allusions to 'Preludes', The Waste Land, 'The Love Song of J. Alfred Prufrock', and 'The Hollow Man'. The most famous of her poems toying with Eliot, however, is 'Waste Land Limericks': a set of witty summaries of the five parts of The Waste Land, with a suitably truncated title: note the dropping of Eliot's definite article, the sort of move sure to upset a pedant, and indicative of her posturing. For example, the 139 lines of part iii, 'The Fire Sermon', are distilled to:

The Thames runs, bottles rattle, rats creep;

Tiresias fancies a peep -

A typist is laid,

A record is played -

Wei la la. After this it gets deep.

(Cocoa, p. 10)

Predictably, 'Waste Land Limericks' has been too much for some critics. In his aforementioned hatchet-wielding review, Peter Riley states that, in Cope's hands, The Waste Land 'can only be parodied by reducing [it] absurdly', and the critic Marta Perez Novales claims 'This is obviously written by someone who finds Eliot's style ludicrous, and makes fun of it'. ${ }^{17}$

However, unlike the 'Nursery Rhyme', 'Waste Land Limericks' is a retelling of a long masterpiece in a form wholly unsuited to it, pointedly devoid of stylistic 
nods to its intertext, and hence not really a parody at all. Moreover, while Cope's poem makes a mockery of the poem most redolent of High Modernism, the comedy is also at the expense of the speaker; as William Logan puts it, 'Waste Land Limericks' is an act of 'cunning insouciance', fully aware of its own ludicrousness. ${ }^{18}$ Not only are the form and register farcically inappropriate vehicles for any rendition of Eliot's poem, there are parts of it Cope's version also 'insouciantly' misunderstands. For example, in the passage quoted above, Cope seems to suggest the 'Wei la la' is the noise of the superficial record the woman in Eliot's poem plays in lines 253-56 of The Waste Land. Eliot's 'Weialala leia / Wallala leialala' in fact echoes the refrain contrasted with that in one of his intertexts, Wagner's opera Götterdämmerung, later in the poem, at lines 266-78 and 290-91. ${ }^{19} \mathrm{Her}$ butchering precis of it is performative ambivalence.

Part II of Making Cocoa for Kingsley Amis is dominated by her invented poet Jake Strugnell, a figure as ludicrous as Cope's versions of Wordsworth or Eliot, and as likely to misunderstand what he is up against as the speaker of 'Waste Land Limericks'. Some of the poems in this half of the book are expressly by 'him', and others might not be - we have no way of knowing. Strugnell, from the unglamorous south London suburb of Tulse Hill, is a man in his forties (forty-three, according to 'From Strugnell's Sonnets' (Cocoa, p. 50)) with a penchant for chasing women without success, aping the poetic styles of his more successful contemporaries, and self-aggrandisement alternating with grimly perspicacious moments of self-reflection. As such, through Strugnell, Cope is able both to parody her contemporary poets, and simultaneously humorously point out the privileges of an anguished archetype. He is a figure of fun, but also a socially advantaged man with the McGonagallian knack of only being good because he isn't, and who is (or would be, if he existed) nonetheless ultimately published in august Faber and Faber covers. That he is himself a parody of a poet with very serious intentions (even if they are hard to take seriously), renders his poems in the style of others imitations on his part. His parodic existence also simultaneously makes each of his poems a double parody - of a paradigm of male poesy, as well as of whatever that paradigm happens to be ripping off - and often prevents us from gleaning 
much about what Cope herself thinks of the aped poets, because 'she' didn't write them.

We are introduced to him in 'Mr Strugnell', one of the poems not explicitly presented to us as having been written by the man himself:

'This was Mr Strugnell's room', she'll say, And look down at the lumpy single bed. 'He stayed here up until he went away And kept his bicycle out in that shed'. (Cocoa, p. 35)

The poem shadows Philip Larkin's famous, 'Mr Bleaney', with which it shares a stanza pattern and narratological trajectory - though Larkin's speaker is the new recipient of the erstwhile room of Mr Bleaney, whereas this speaker looks beyond the current occupant's presence in a moment of grim prolepsis: the landlady will end the monologue imagined for her by saying that $\mathrm{Mr}$ Strugnell is now 'Enjoying perfect boredom up in Hull'. In a manner reminiscent of her 'Nursery Rhyme as it might have been written by T. S. Eliot', the poem is littered with ludicrous variants of lines and phrases from Larkin's poem, such as the daftly tautological third line above, a counterpart to Larkin's 'he stayed, / The whole time he was the Bodies till, / They moved him'.

Moreover, it conflates Strugnell's habits with those of Mr Bleaney's author, himself the poet most identified with the emotionally detached, unromantic and domestic tropes of Movement poetics, which dominated British poetry in the 1950s and 1960s. As Nicola Thompson summarizes, 'Cope uses Movement methodology to subvert Movement ideology', and that use of 'Movement methodology' comprises the content as well as the form. ${ }^{20}$ In that first stanza, we learn of Strugnell's Larkinesque habits of riding a bicycle and sleeping in a single bed: Larkin lived alone most of his life and we soon gather that Strugnell is not an especially eligible bachelor. His desire for 'perfect boredom' in Hull alludes both to where Larkin lived for thirty years, and Larkin's poem 'Dockery and Son', which contains the line 'Life is first boredom, then fear', so at least Strugnell isn't yet heading for the worse of those two eventualities. ${ }^{21}$ In 
'Mr Strugnell' we discover that, like Larkin, he works in a library (in Strugnell's case, the provincial branch at Norwood) and loves jazz - though this and the accompanying sound of his tapping foot had been 'a bore' to the landlady, which she took in her stride, whereas in Larkin's poem the male speaker is left 'Stuffing my ears with cotton wool to drown / the jabbering set' used by his landlady. ${ }^{22}$ We also find out that Strugnell 'had a funny turn in sixty-three / And ran round shouting "Yippee! It's begun"', though again this is a comedic misrepresentation, for in the Larkin poem it alludes to, 'Annus Mirabilis', a hangdog speaker laments that the apparent sexual liberation of 1963 was 'rather late for me' ${ }^{23}$. We also learn that he likes 'John Betjeman very much indeed' - again, much like Larkin, who regarded Betjeman as the joint 'greatest living English poet'24 - but also that he is a man who likes to read the work of men, dismissing Pam Ayres and Patience Strong as 'too highbrow', a clear indication he hasn't bothered to read them. As such, 'Mr Strugnell' makes a composite caricature of both Larkin and his poem, pinning Strugnell to it, so that all three come out looking pathetic.

The next poem, 'Budgie Finds His Voice', parodies Ted Hughes - or is a work of pale imitation, if we suspend our disbelief enough and accept its subtitle: 'From The Life and Songs of the Budgie by Jake Strugnell.' This echoes the full title of Hughes's 1972 collection Crow: From the Life and Songs of the Crow. So, Budgie might find his voice, but Strugnell only finds a bargain-basement version of someone else's. Its closest intertext in Crow is 'That Moment', and much of the wit in Cope's poem is in its proximity to that text. Both are single sentences, with the main clause saved for a final, isolated line. Both describe an apocalyptic scene, with the last human gone (in Hughes's poem he appears to commit suicide), and only a bird left to pick over the ruins. Moreover, Cope/Strugnell replicates the construction and cadences, if crucially not the connotations or gravity, of Hughes's images. Hughes's poem begins:

When the pistol muzzle oozing blue vapour

Was lifted away

Like a cigarette lifted from an ashtray $\cdot . .{ }^{25}$

The second stanza of the Cope/Strugnell counterpart reads: 
When the sun was lifted away

Like an orange lifted from a fruit bowl...

(Cocoa, p. 37)

Gone is the delayed rhyme, the delay caused by the enjambments of Hughes's second line, the comparison of things ostensibly alike and uncannily different in purpose. Instead, Cope/Strugnell makes the huge bathetically insignificant, the sun becoming a piece of fruit. Likewise, the body in Hughes's poem, prone on gravel, abandoned, is replaced with the implausibly solitary 'last ear on earth' which 'lay on the beach / Deaf'. But the biggest dose of bathos is saved for the final line. Hughes's poem ends with Crow looking for something to eat: he carries on, dispassionately. So does Budgie: “'Who's a pretty boy then?" Budgie cried'. Like Strugnell the unsuccessful poet, Budgie is left mindlessly professing his superficial worth to nobody.

To what extent is Cope dismissing her lauded male peers, such as Eliot, Larkin, Hughes? As Henry King has pointed out, Cope's parodies 'aren't simple lampoons: they imply the respect necessary to such telling imitations' ${ }^{26}$ However critical or laced with mockery, a good parody requires engagement, not dismissal, and often comes from a position not of loathing or ambivalence, but admiration. This is certainly the norm for Cope. Indeed, she has said that some of her earliest poems, written before any collected in her debut book, were 'poor imitations of T. S. Eliot', ${ }^{27}$ she has described Larkin's poetry as having 'knocked me sideways', ${ }^{28}$ and her admiration for Hughes has been both considerable and mutual. For example, she has recalled beginning to write poems after teaching Ted Hughes; ${ }^{29}$ and in 1992, on the publication of her second collection, Serious Concerns, Hughes wrote to Cope to congratulate her on her 'deadpan fearless sort of way of whacking the nail on the head when everybody else is trying to hang pictures on it' ${ }^{30}$

Cope's editor for her first book was the poet Craig Raine, hugely famous at that time for his 'Martian' poems, such as those collected in A Martian Sends a Postcard Home(1979), which engaged with unusual similes - making him at the time almost, at least superficially, the metaphysical poet for the late twentieth century. ${ }^{31}$ His own debut collection, The Onion, Memory (1978), 
opens with a section called 'Yellow Pages', comprising seven poems about the working lives of men engaged in the sort of manual labour Raine had no need to do, such as 'The Butcher', 'The Gardener', and 'The Window Cleaner'. ${ }^{32}$ In this context, Cope's solemn focus in 'The Lavatory Attendant', on the dismayed lot of a man with one of the least glamorous jobs going, can be regarded as a pointed ratcheting up of consummate affectation. He is pictured, sententiously, not as an overall-wearing bloke in the loos, but as a man of the cloth, in 'sacerdotal white', guarding 'a row of fonts // With lids like eyepatches' (Cocoa, p. 39), and this sub-metaphysical conceit is a blatant mockery of those favoured by Raine and his fellow 'Martians'. As he guards a 'row' of them, and does not allude to urinals, it is possible he is working the Ladies'. In any case, at the end of a day of mopping up after 'Short-lived Niagaras', he symbolically - though only symbolically - equalizes his servitude: 'He turns Medusa on her head / And wipes the floor with her.'

This poem sits second in a run of four poems also parodying Ezra Pound and Basil Bunting (apparently together, though possibly Bunting in one of his most Poundian phases), Seamus Heaney, and Geoffrey Hill. None are attributed to Strugnell, though as they are in the section in which 'his' work appears it is impossible to be sure that the parody is not refracted through her fictional poet. What follows these, however, is certainly a parody refracted through her bard of Tulse Hill. With its simple refrain of love and yearning, 'thinking of you', repeated five times across nine lines over the space of two pages, 'Strugnell in Liverpool' finds Strugnell playing at being the popular Liverpool poet Adrian Henri, who litters his 1969 book-length poem Citywith the same phrase.

Henri's poem is frenetic, full of quotidian narratives, memories, and ephemeral consumer goods, punctuated by the constant of an absent 'you':

thinking of you

coming home

cat waiting black bigeyed in the hall

for Kit-E-Kat

going out again 
leaving her rolled up sleeping warm catdreams on the settee

thinking of you

thinking of you $^{33}$

'Strugnell in Liverpool' tells the 'story' of Strugnell's solitary morning: waking alone, going naked to the toilet, getting dressed, then thinking of the 'pink / nylon panties', 'blue / nylon bra' and 'white / nylon panties' of the object of his apparent devotion (Cocoa, pp. 42-43). Those brash enjambments, and others like it throughout the poem, are clearly intended to evoke Henri's heavily enjambed switchbacks of thought and impression, with the caveat that Strugnell reveals his limitations by artlessly cutting through syntactical units rather than laying them one below the other as Henri tends to do. He is a bad imitator, and the joke is on him more than on Henri. Like Henri and the other poets who appeared with him in the phenomenally popular anthology The Mersey Sound (1967), Roger McGough and Brian Patten, his poem is also scattered with low-brow references, normally to branded goods - though what he is doing 'alone in the toilet' (aren't we usually?) with 'the Andrex / thinking of you' might be given away by him then immediately 'eating my cornflakes', which were of course invented to dissuade 'troubled masturbators from the sinful act'. ${ }^{34}$ As with 'Budgie Finds His Voice', the poem simultaneously shows Strugnell desperate to cling to the coat-tails of a more popular contemporary, thereby finding no voice of his own, and revealing more about his tendencies than he might have intended.

'God and the Jolly Bored Bog-Mouse' takes Strugnell's proclivity for imitation a step further. The poem is subtitled 'Strugnell's entry for the Arvon/Observer Poetry Competition 1980. The competition was judged by Ted Hughes, Philip Larkin, Seamus Heaney and Charles Causley'. (This male-only, white-only lineup is almost unthinkable in our times; the competition was won by Andrew Motion.) True to form, Strugnell provides a poem at once derivative and banal, and therefore insulting to its intended audience: Cope has observed that 'people who are too focused on being published tend not to get anywhere', and Strugnell is the apotheosis of that temperament. ${ }^{35}$ Each of the poem's four stanzas follows the same pattern of derivations. This is the third: 
Mouse dreamed a Universe of Blood, He dreamed a shabby room, He dreamed a dank hole in the earth, (back to the jolly womb).

(Cocoa, p. 45)

The first lines of each stanza, then, echo Hughes (here, Crow, again), the second Larkin (here, 'Mr Bleaney', again), and the third Heaney (here, the 'bog poems' mainly collected in his 1975 collection North). The poem is in ballad stanzas, a form favoured by Causley, and the fourth lines, each containing the word 'jolly', echo Causley's 'I Saw a Jolly Hunter', in which the word is repeated with increasingly bitter implications in almost every line ${ }^{36}$ Again, as we work through his bizarre narrative yoking together of clichéd versions of their different sensibilities and styles, it is clear that the joke is on Strugnell and other poets with some of his motivations more than it is on the poets 'he' emulates so feebly.

'God and the Jolly Bored Bog-Mouse' is followed by the longest piece in the book, though we are encouraged to believe that it is in fact only an excerpt. 'FromStrugnell's Sonnets' provides poems 'i' to 'vii' in the sequence, though given the length of sequences by his Renaissance models, who knows how long Strugnell might go on for ${ }^{{ }^{37}}$ Each is a Shakespearean sonnet, and begins with a line, often slightly altered, from the start of one of Shakespeare's, though not its corresponding number, and with nods to other Renaissance sonneteers. Moreover, thematically, the sequence is a base equivalent to most of its Renaissance counterparts, concerned as it is with a form of love-longing for an absent flame. Thus, in the first, the start of Shakespeare's 'Sonnet 129', 'Th' expense of spirit in a waste of shame / Is lust in action', becomes 'The expense of spirits is a crying shame', and Shakespeare's analysis of the pursuit, experience and memory of lustful passion is, in a pun on 'spirit', reduced to a lament that women are out of reach because they like expensive drinks and won't 'come across on half a pint of beer' (Cocoa, p. 46). We might be reminded of U. A. Fanthorpe's famous poem 'Not My Best Side', an ekphrastic parody of the legend of George and the Dragon, in which an equally 
belligerent male warns the damsel against 'being choosy', and reveals his narrow ambitions, sense of entitlement, and sad vulnerability. ${ }^{38}$

This rather sets the tone for the whole (excerpt of the) sequence. The second sonnet begins with the opening line of Shakespeare's 'Sonnet 14', 'Not from the stars do I my judgement pluck', though whereas Shakespeare's speaker rejects astrology, Strugnell has read his horoscope for the day and readily accepts its promise of 'luck / With money and girls' (Cocoa, p. 47), the first of which would apparently have solved his problem with the second in the opening sonnet. The end of the poem is less Sidney's Astrophel and Stellastar-gazer and star - than horoscope-gazer and mirror: Cancerians 'make fantastic lovers, warm and gentle', though it is 'Amazing' that the object of his devotion fails 'to see / How very well all this applies to me'. Then in 'iii', we learn that he turned to writing poetry in an attempt to win her and other women round, in the belief they 'love a bard, however dire, / And overlook my paunch because I write' (Cocoa, p. 48) - though of course they don't, as the second sonnet has revealed.

Sonnet 'iv' then turns from Shakespeare's 'Sonnet 55' to 'Sonnet 18', to end with a moment of less vainglorious self-reflection: 'your beauty and my name will be forgotten - / My love is true, but all my verse is rotten' (Cocoa, p. 49). He writes poems, of all things, for what they might bring him now in love and riches, with no delusory eye on posterity. In ' $v$ ', we gather that Strugnell lost the presumably younger object of his affections when his musical tastes reminded her of her father's, and 'vi' begins with a bitter counterpart to the opening of Shakespeare's 'Sonnet 116': 'Let me not to the marriage of true swine / Admit impediments' (Cocoa, p. 51). She has gone off with a new man and his 'big car', leaving Strugnell to dedicate himself to the 'Higher Things' he has already made clear he doesn't intrinsically care for. It ends:

One day I'll make my mark,

Although I'm not from Ulster of from Mars, And when I'm published in some classy mag You'll rue the day you scarpered in his jag. 
It is as though Strugnell has read 'Engineers' Corner' and taken it at face value. Again, Cope (through Strugnell) swipes at some of her largely male contemporaries, at a time when several poets in Northern Ireland, such as Heaney, Michael Longley, and Derek Mahon, were popular and often writing about the ongoing Troubles, and the aforementioned 'Martian poets' such as Raine and Christopher Reid were in their first flush of popularity. Unfortunately for Strugnell, Tulse Hill just isn't very exciting, and the literary greatness he seeks for non-artistic reasons remains a pipe dream as he advances through middle age and farther off the radar of the young women who will never become less alluring to him.

The final sonnet presents Strugnell meditating bitterly on using poetry to vanish into misanthropic solipsism. However, in true Strugnellian fashion, that isn't achieved by absorbing himself in poetry, but by using a book of it as a dull siren to warn people off talking to him during a train journey; it seems if he has learned anything, it is that poetry won't get him the girl, and might in fact make him a pariah, and by now he has given up enough to embrace that reality. Again, he (and she) takes aim at a famous male contemporary of whom Strugnell and his ilk would be monumentally jealous:

Recent research in railway sociology

Shows it's best to read the stuff aloud:

A few choice bits from Motion's new anthology

And you'll be lonelier than any cloud.

(Cocoa, p. 52)

As István D. Rácz has noted, 'support and subversion coexist in her Strugnell poems' ${ }^{39}$ This anthology can only be The Penguin Book of Contemporary British Poetry, edited by Andrew Motion and her former poetry tutor Blake Morrison. In addition to including some of Motion's own poetry, it contains work by two of the poets parodied in Making Cocoa for Kinglsey Amis, Seamus Heaney and Craig Raine, and has often been criticized for its perceived parochialism, gender imbalance, and inclusion of Irish poets - none of which are Strugnell's concerns, of course. ${ }^{40}$ We might fairly assume that the rest of 'Strugnell's 
Sonnets' slip increasingly into the vortex of his navel; Cope spares us the details.

The book's second section ends with Strugnell's attempts at minimalism, as this antithesis of a Zen sensibility turns his hand to haiku. The first of the three 'Strugnell's Haiku' reads:

The cherry blossom

In my neighbour's garden - Oh!

It looks really nice.

(Cocoa, p. 55)

True to the expectations of the form, we have the syllabic constraint, two natural images, the evocation of a season; true to Strugnell, the poems vanish into bathos in the first, self-obsession in the second (in which 'my hair also' falls), and baser desires in the third ('pubs are open'). Here, at least for this collection, we leave him, sure that his sudden interest in brevity is not a sign he is about to give up altogether on his bardic dreams. Her next collection, Serious Concerns (1992) would prove otherwise. Strugnell was too useful a stooge for needling her male-dominated contemporary poetic culture.

However, Cope is no ideologue, and in a final twist she wittingly and wittily undermines herself. The last poem in the book, given added prominence by being separated alone in section III, is the title poem, 'Making Cocoa for Kingsley Amis'. The title was apparently a 'dream', a record of which seemed 'vital', even though it 'wouldn't be much of a poem' (Cocoa, p. 59). There is something comically irreverent, then, about making this the title poem. It seems the move of a poet who refuses to take herself too seriously - or perhaps seriously enough. If we take the speaker to be Cope, and nothing suggests otherwise, it is also a poem in which a woman, in the unwilled subconscious of dreaming, serves a man.

At the end of the collection, then, she records the 'vital' dream which playfully undermines all of the book's subtle and less subtle jibes at gendered habits and adherence to traditional gender roles. In the earlier poem 'My Lover', she celebrates a partner for minor acts of selflessness and devotion, including, 
among other things, making her 'smooth cocoa'; contrastingly, in the final poem, she envisages making cocoa for a man. Doing so is therefore perhaps also symbolic of a sense of literary hierarchy: Cope was yet to publish a book when she wrote it, and in the year she did, Amis won the Booker Prize for his nineteenth novel, The Old Devils. Amis, a great comic writer, can be seen to represent an aspiration, and a dream about making him cocoa can, perhaps by an overenthusiastic extension, be regarded as a displacement of her own subconscious and conscious desire to emulate. At any rate, despite, in Christopher Reid's words, 'ruthlessly mocking literary pretentions and absurdities', the book ends doing what it has done so many times already: paying homage to a literary hero without kowtowing to him. ${ }^{41}$ Making Cocoa for Kingley Amis asks where a woman can fit into this overwhelmingly male tradition. Moreover, in answering not only with biting, nuanced and layered parodies, but with direct poems of love and longing that have become part of that tradition, it offers a riposte to Amis's assertion in his poem 'A Bookshop Idyll' that, whereas men can 'get by without' love, 'Women don't seem to think that's good enough - / They write about it'. ${ }^{42}$ In a final, playful, act of revenge, she eponymously dedicated her book to him.43

Rory Waterman is Senior Lecturer in English at Nottingham Trent University, where he leads the MA Creative Writing. His books include Poets of the Second World War(Northcote House, 2016) and Belonging and Estrangement in the Poetry of Philip Larkin, R. S. Thomas and Charles Causley (Routledge, 2014), as well as two poetry collections with Carcanet Press. He writes regularly for many periodicals, most frequently the $T L S$, and co-edits New Walk Editions.

\section{Footnotes}

1

Anthony Thwaite, Poetry Today: A Critical Guide to British Poetry 196095 (London: Routledge, 1996), p. 127.

2

'Desert Island Discs', BBC Radio 4, 1 February 2019.

3

Robert Nye, 'Max the Parodist in Skirts', in The Times, 13 March 1986, p. 13. The title of that article indicates the position of women authors as 'other' in not too 
distant living memory. Max Beerbohm (1872-1956) was a parodist and caricaturist, and the author of the novel Zuleika Dobson (1911).

4

Over 180,000 by 2018 , according to $<w w w$.poetryarchive.org $>$ [accessed 9 October 2018].

5

Peter Riley, 'Making Money', in PN Review 13.1 (1986), p. 79. Cope is also largely ignored by feminist critics. For example, she receives no mention in Vicki Bertram, Gendering Poetry: Contemporary Poetry and Sexual Politics (London: Rivers Oram, 2005).

6

Wendy Cope, Making Cocoa for Kingsley Amis (London: Faber, 1986), p. 3. Hereafter abbreviated to 'Cocoa'.

7

According to Cope's own notes on the poem. See Wendy Cope, 'Wendy Cope: Making Cocoa for Kingsley Amis', in the Guardian, 18 May 2013 $<$ https://www.theguardian.com/books/interactive/2013/may/18/wendy-copemaking-cocoa-kingsley-annotations $>$ [accessed 11 June 2018]. 8

Tony Harrison, Laureate's Block and Other Poems (London: Penguin, 2000), p. 12. Ten years later, when Motion's decade-long tenure was drawing to an end, Cope made her feelings on the Laureateship known: 'it is an archaic post and means nothing.' See 'Female Contenders Rule Out "Archaic" Post of Poet Laureate', in the Independent, 10 June 2008

$<$ https://www.independent.co.uk/arts-entertainment/books/news/femalecontenders-rule-out-archaic-post-of-poet-laureate-843537.html> [accessed 9 October 2018].

9

Richard Collins and James Purnell, 'Introduction', in Reservoirs of Dogma, ed. by Richard Collins and James Purnell (London: Institute for Public Policy Research, 1996), pp. 1-9 (p. 3).

10

Louise Tondeur, 'Risk, Constraint, Play: A New Paradigm for Examining Practiceresearch in the Academy', in Text Journal 21.1 (2017)

$<$ http://www.textjournal.com.au/april17/tondeur.htm> [accessed 9 October 2018].

11

See, for example, Wendy Cope, 'Ageing' (2011), reprinted in Wendy Cope, Life, Love and the Archers (London: Two Roads, 2014), pp. 171-75 (p. 172).

12

See <http://im-possible.info/english/art/delprete> [accessed 9 October 2018]. 
13

'Libra is the sign of partnerships and relationships. ... Libra feels weak on its own'. See Joanna Martine Woolfolk, Libra (Plymouth: Taylor Trade Publishing, 2011), p. 3.

14

Andrew Bennett, 'Romantic Poets and Contemporary Poetry', in The Cambridge Companion to British Romantic Poetry, ed. by James Chandler and Maureen N. McLane (Cambridge: Cambridge University Press, 2008), pp. 263-78 (p. 270). 15

William Wordsworth and Samuel Taylor Coleridge, Lyrical Ballads (1800), ed. by R. L. Brett and A. R. Jones (London: Routledge, 2005), p. 204.

16

William Kerr, 'Counting Sheep', in Georgian Poetry V, ed. by Edward Marsh (London: Poetry Bookshop, 1922), p. 112.

17

Riley, p. 79; Marta Pérez Novales, 'Wendy Cope's Use of Parody in Making Cocoa for Kingsley Amis', Miscelánea: A Journal of English and American Studies, 15 (1994), 481-500 (p. 488).

18

William Logan, 'A Letter from Britain (Part II)', in Poetry 157.5 (1992), 290-99 (p. 293).

19

T. S. Eliot, The Waste Land and Other Poems (London: Faber, 1999), pp. 32-33. 20

Nicola Thompson, 'Wendy Cope's Struggle with Strugnell in Making Cocoa for Kingsley Amis', in New Perspectives on Women and Comedy, ed. by Regina Barreca (Philadelphia, PA: Gordon and Breach, 1992), pp. 111-22 (p. 116).

21

Philip Larkin, The Complete Poems, ed. by Archie Burnett (London: Faber, 2012), p. 66.

22

Ibid., p. 50.

23

Ibid., p. 90.

24

Alongside T. S. Eliot. See John Shakespeare, 'Larkin's First Interview: How Philip Larkin Rewrote the First, Indiscreet Article About Him to Appear in the British Press', in The Times Literary Supplement, 1 April 2009, p. 12.

25

Ted Hughes, Crow (London: Faber, 1972), p. 22.

26 
Henry King, 'Memorable Speech', PN Review, 35.2 (2008), 79-80 (p. 80).

27

Wendy Cope, 'It's a Free Country' (2008), reprinted in Life, Love and the Archers, pp. 145-46 (p. 145).

28

Wendy Cope, 'Larkin's “First Sight”' (2001), reprinted in Life, Love and the Archers, pp. 217-18 (p. 217).

29

See Wendy Cope, 'Ted Hughes in the Classroom' (1999), reprinted in Life, Love and the Archers, pp. 79-81.

30

Wendy Cope, Two Cures for Love: Selected Poems 1979 - 2006 (London: Faber, 2008), back cover.

31

According to Cope, Raine also suggested that the title poem should have its own section at the back of the book and, in fact, be made the title poem. See $<$ https://www.theguardian.com/books/interactive/2013/may/18/wendy-copemaking-cocoa-kingsley-annotations $>$ [accessed 9 October 2018]. She has given him 'special thanks for believing in my ability to write'. See 'Introduction', in Life, Love and the Archers, pp. 1-3 (p. 3).

32

Craig Raine, The Onion, Memory (Oxford: Oxford University Press, 1978), pp. 2-8. 33

Adrian Henri, Collected Poems: 1967-85 (London: Allison and Busby, 1986), p. 105.

34

Lulu Morris, 'Cereal Masturbation', National Geographic (2018)

$<$ https://www.nationalgeographic.com.au/history/cereal-masturbation.aspx> [accessed 9 October 2018].

35

Wendy Cope, 'Introduction' to How to Write Poetry (2008), a booklet published by the Guardian. Reprinted in Life, Love and the Archers, pp. 144-46 (p. 146). 36

Charles Causley, Collected Poems, 1951-2000 (London: Picador, 2000), p. 215. 37

For example, Philip Sidney's Astrophel and Stella (1591) contains 108 sonnets, Edmund Spenser's Amoretti (1594) 88, and Shakespeare's Sonnets (1609) 154. 38

U. A. Fanthorpe, Selected Poems (London: Penguin, 1986), pp. 28-29.

39 
István D. Rácz, 'Heaneys of the Mind', Hungarian Journal of English and American Studies, 10.1/2 (2004), 127-36 (p. 135).

40

The Penguin Book of Contemporary British Poetry, ed. Andrew Motion and Blake Morrison (London: Penguin, 1982). Of its 21 poets, 16 are men - largely reflective of the gender split in British poetry publishing at the time, but also a reminder that in many ways Cope wrote the book in a predominantly male poetry world, much more so than our current one. Heaney is the first poet in the book, which might surprise anyone who knows how British he felt. In 'An Open Letter', first published in 1983, he writes: 'My passport's green. / No glass of ours was ever raised / To toast The Queen'. See Seamus Heaney, An Open Letter (Dublin: Field Day, 1983).

41

Christopher Reid, 'Here Comes Amy', London Review of Books, 8.7 (1986), 20-22 (p. 22).

42

Kingsley Amis, Collected Poems: 1944-1979 (New York, NY: New York Review of Books, 2016), p. 56.

43

Though the book also contains a specific dedication 'to Arthur S. Couch and everyone who helped'. The appropriately-named Couch was her therapist. 'Everyone else' must surely include the men parodied in the book. 